\title{
ACTIVITIES WITH CULMINATION
}

\author{
FÁTIMA OLIVEIRA E ANTÓNIO LEAL
}

\section{RESUMO}

Neste artigo, discutimos um problema debatido há muito sobre a natureza aspetual de certas predicações, classificadas como Activities e Accomplishments (Vendler 1957, e outros). Este problema foi já colocado de maneira informal por vários autores, que assinalaram a complexidade dos Accomplishments, mas só mais recentemente houve tentativas de formalização que explicasse a alternância entre estes tipos aspetuais que é desencadeada pelas propriedades denotacionais de um dos argumentos de certos verbos.

Tendo em conta alguns dados do Português Europeu, propomos que os verbos podem ter informação lexical que é relevante para a determinação da presença ou ausência de telicidade nas predicações em que ocorrem. Assim, certos traços verbais restringem a composição aspetual da predicação, mas há casos em que o perfil aspetual é definido em função do processo composicional envolvido, uma vez que o verbo não é marcado com esses traços. Neste trabalho, apenas foi considerada a contribuição de certos argumentos internos tendo em conta a sua natureza denotacional (cumulativo / não cumulativo).

Propomos ainda que, nos casos em que os verbos não são lexicalmente marcados com os traços anteriormente referidos, a predicação não pode ser classificada à partida como Activity ou Accomplishment.

\section{[1] INTRODUCTION}

In many aspectual classification proposals, Accomplishments are considered a particularly problematic class (cf. Verkuyl 1972; Mourelatos 1978; Bach 1986; Tenny 1987, among many others), as this class raises several problems not only from a theoretical point of view but also from a data analysis point of view. Although there are, in the past, some proposals regarding how to formalize their semantics (cf. Verkuyl 1993), a particular attention has been paid recently to Accomplishments (cf. Rothstein 2004, 2012; Piñon 2006, among others).

From a theoretical point of view, it should be pointed out that, in the majority of aspectual classes proposals, the class of Accomplishments ${ }^{1}$ presents the greater

[1] The term "accomplishment" is used originally in Vendler (1957) in a proposal describing the different types of situations based on Aristotle and Kenny (1963). There are, however, other proposals, like Mourelatos (1978), Bach (1986), Moens (1987), Smith (1991). These proposals are all based on Vendler's classification. For a different proposal built, according to the author, specifically for Portuguese, see Santos (1996). 
structural complexity, reflecting the combination of two properties: duration and telicity. This can be observed, just to mention some examples, in Moens' (1987) and Rothstein's (2004) proposals. In the first case, Accomplishments (or, in Moens' terminology, Culminated Processes) are the only type of events that present, in their aspectual nucleus, two eventive phases, the preparatory process and the culmination point. In this classification, Achievements (or Culminations) exhibit, in the aspectual nucleus, only a culmination point and Activities (Processes) show only a preparatory process. In the second case, Rothstein (2004), using an event semantics, proposes that the structure of Accomplishments comprises two sub-events. One of these sub-events corresponds to an Activity and the other to an incremental durative change of state event and these two sub-events share an argument, the incremental theme. As a consequence of this view, Accomplishments would be a derived class, built on basic eventualities.

Taking into consideration data analysis problems in European Portuguese (EP hereafter) and in other languages (cf. Krifka 1995; Filip 1999; Piñon 2006, among others), the predications classified as Accomplishments arise, in most cases, as a result of the combination of certain aspectually relevant properties of the verb with some properties of another constituent of the predication. The latter is typically an internal argument but could also be an external argument or an adjunct (cf. Mourelatos 1978; Tenny 1987; Dowty 1991; Ramchand 1997, among others). So we generally agree with Mourelatos (1978), when he says that, for the analysis of verb predication, "a total of six factors are involved: (a) the verb's inherent meaning; (b) the nature of the verb's arguments, i.e., of the subject and of the object(s), if any; (c) adverbials, if any; (d) aspect; (e) tense as phase, e.g., the perfect; (f) tense as time reference to past, present, or future" (Mourelatos 1978, pg. 421).

As the definition of the Accomplishments aspectual profile does not depend solely on the verb itself but on the combination of the verb together with other elements of the predication, this raises a number of problems regarding the aspectual classification of some predications. This can already be noticed in Vendler (1957, pg. 145), who remarked that adding a direct object could change the aspectual nature of a predication with a verb like 'run'. Dowty (1979) also points out that an Activity verb describing movement behaves like an Accomplishment verb when it co-occurs with a destination locative or an adverbial of extension, as in (1):

(1) John walked a mile/ to the park (in an hour) (Dowty 1979, pg. 60)

Moreover, Dowty (1979) considers that any Activity verb can behave, in the right contexts, as an Accomplishment and that some verbs classified as Accomplishments can be classified as Activities when the direct object is an indefinite plural or a mass noun, as it was already pointed out in Mourelatos (1978, pg. 427).

These considerations lead to the question of how to classify these verbs (see also Verkuyl 1993, who elaborates his ideas put forward in Verkuyl 1972) and 
moreover how to establish a relation between two predications like (2-a), classified as an Activity (an atelic event), and (2-b), classified as an Accomplishment (a telic event). Putting it in another way, would it be the case that the verb beber (to drink) projects an eventuality of the type Activity which is subsequently commuted to an Accomplishment via a quantized direct object (see Krifka 1992, 1998), or would it be the case that the same verb projects an Accomplishment which is commuted to an Activity via a cumulative direct object?

(2) a. O Rui bebeu água

The-Rui drank water

Rui drank water

b. O Rui bebeu um copo de água

The-Rui drank a glass of water

Rui drank a glass of water

A way to avoid this problem is to assume that the aspectual classes are defined at verb phrase level and not at verb level, so that (2-a) would be a basic Activity while (2-b) would be a basic Accomplishment (cf. de Swart 1998; Rothstein 2004 among others). Nevertheless, this does not explain the relation between the two sentences and it does not explain either why we do not see a parallel behaviour with other types of verbs where the contrast cumulative/quantized direct objects does not trigger aspectual shift (cf. Rothstein 2012). This can be illustrated by (3), where the contrast between quantized and cumulative direct object o carrinho/areia (the cart/ sand) does not produce any aspectual change:
a. O Rui
empurrou $o$
carrinho
(*em 5 minutos/
durante 5 minutos) ${ }^{2}$
The-Rui pushed the cart
(in 5 minutes/
for 5 minutes)
Rui pushed the cart (*in 5 minutes/ for 5 minutes)
b. O Rui empurrou areia (*em 5 minutos/durante 5 minutos) The-Rui pushed sand (in 5 minutes/for 5 minutes)
Rui pushed sand ( ${ }^{\text {in }} 5$ minutes/for 5 minutes)

Moreover, the simple assumption that aspectual classes are defined at verb phrase level does not explain why the quantized/cumulative direct object alternation does not give rise to aspectual shifts involving other aspectual classes. This can be illustrated in (4), where (4-a) and (4-b) are states, irrespective of the direct object being uma mulher (quantized direct object) or poesia moderna (cumulative direct object), and (4-c) and (4-d) are degree achievements (cf. Dowty 1979; Hay

[2] We use the standard written symbol '*' to mark the ungrammaticality of the examples, and ' $\#$ ' to point out that the example is acceptable but it does not exhibit the relevant interpretation. 
et al. 1999; Kennedy \& Levin 2008, among others), irrespective of the direct object being um prato de sopa (quantized direct object) or sopa (cumulative direct object).
a. O João adorou uma mulher
The-João adored a woman
João adored a woman.
b. O João adorou poesia moderna
The-João adored modern poetry
João adored modern poetry.
$\begin{array}{llllll}\text { c. O João aqueceu um prato de sopa. } \\ \text { The-João } & \text { warmed up a bowl of soup }\end{array}$ João warmed up a bowl of soup.
d. O João aqueceu sopa. The-João warmed up soup João warmed up some soup.

[2] FILIP (1999) AND PIÑON (2006) PROPOSALS AND EP DATA

Filip (1999) puts forward a proposal for solving this problem ${ }^{3}$. According to her, the verbs with an incremental theme argument belong to a particular type of eventuality, incremental eventuality. This type of eventuality is of a lexical nature in the sense that this classification is ascribed to a verb as a non saturated predicate, that is, a predicate only with variables in its argument positions. In Filip's proposal verbs can be classified as [- quantized] or [+ quantized], corresponding the former to States and Activities and the latter ones to the other events. However, the incremental eventualities have in their basis a verb specified as [ $\alpha$ quantized], that is, this kind of verbs is specified with an indeterminate value for quantization. So, these predicates would be telic or atelic according to the quantized or cumulative nature of their incremental theme argument, or any other incremental argument satisfying a homomorphism to the argument event.

This proposal, based on the notion of quantization, faces some problems when we look at some EP data. In Filip's (1999) proposal the incremental eventualities are related to the property of quantization, but a sentence like (5), for instance, denotes a quantized predicate (as there is no proper part of vaguear até à praia (wonder up to the beach) that is vaguear até à praia) but it is not telic, as we can see by the application of the temporal adverbials test compatibility.

[3] For different perspectives or proposals, see Mourelatos (1978); Declerck (1979); Carlson (1981); Tenny (1987); Dowty (1991); Depraetere (1995); Ramchand (1997); Krifka (1998), among others. 
(5)

$\begin{array}{r}\text { O rapaz vagueou até à praia } \\ \text { (*em meia hora/ } \\ \text { durante meia hora) } \\ (* \text { in half an hour/ } \\ \text { for half an hour })\end{array}$
The boy wandered up to-the beach wandered up to the beach (*in half an hour/for half an hour)

Another problem is the existence of verbs that project eventualities of incremental type, but the alternation of the quantized/cumulative status of the incremental theme argument does not cause any change in the telicity of the predication, as in (6).

(6) a. O rapaz almoçou um prato de sopa (\# durante 10 minutos/ em dez minutos) The boy lunched a bowl of soup (\#for 10 minutes/ in 10 minutes)

The boy had a bowl of soup for lunch (\#for 10 minutes/in 10 minutes)

b. O rapaz almoçou sopa (\# durante 10 minutos/em dez minutos) The boy lunched soup (\#for 10 minutes/in 10 minutes) The boy had soup for lunch (\#for 10 minutes/in 10 minutes)

Examples like (6) show that, in incremental eventualities, it is not always possible to associate the quantization of the incremental theme to telicity and its cumulativity to atelicity.

A similar idea, that is, there are not just two classes of durative events (Activities and Accomplishments), but possibly three classes is also developed in Piñon (2006). Based on data from Hungarian, Piñon proposes a division of Accomplishments in Strong Accomplishments and Weak Accomplishments. The first ones are incompatible with bare plural direct objects and give rise to two readings (presuppositional and scalar) when they occur in the scope of operators like almost. The second ones are compatible with bare plural direct objects and give rise only to the presuppositional reading when they occur in the scope of operators like almost, being in this respect similar to Activities. However, the data from EP does not confirm this kind of division, as there is no restriction to the type of direct object, differently from Hungarian, as we can see by the contrast between (7-a) and (8-a) where the first one admits two possible interpretations (as shown in (7$\left.\mathrm{a}^{\prime}\right)$ and (7-a")) but the second one only admits one interpretation (see (8-a')). On the other hand, when a verb combines with a bare plural (cf. (8-a)), the test with almost shows only the presuppositional reading (similar to Hungarian), but the predication is not telic, since it does not combine with in $x$ time, but with for $x$ time only (cf. (8-b)). 
(7)
a. O rapaz quase comeu a maçã
The boy almost ate the apple
The boy almost ate the apple
$a$ ' $\rightarrow$ O rapaz não começou a comer a maçã
The boy not started to eat the apple
The boy didn't start eating the apple
a" $\rightarrow$ O rapaz não acabou de comer a maçã
The boy not finish of eat the apple
The boy didn't finish eating the apple
b. O rapaz comeu a maçã em 5 minutos
The boy ate the apple in 5 minutes
The boy ate the apple in 5 minutes

(8) a. O rapaz quase comeu maçãs

The boy almost ate apples

The boy almost ate apples

The boy not started to eat apples

The boy didn't started eating apples

a" $\rightarrow$ O rapaz não acabou de comer maçãs

The boy not finish of eat apples

The boy didn't finish eating apples

b. O rapaz comeu maçãs (* em 5 minutos/durante 5 minutos)

The boy ate apples (*in 5 minutes/for 5 minutes)

The boy ate apples (* in 5 minutes/for 5 minutes)

\section{[3] “ACCOMPlishaBle” ACtivities}

In order to find a way towards solving this puzzle, we propose ${ }^{4}$ that verbs do carry some information concerning the telicity of the predications they project. And we consider telicity as the property of the predications that denote eventualities having a set terminal point and a consequent state (cf. Garey 1957; Moens 1987, among others $)^{5}$ associated to it.

In other words, there are eventualities whose final boundaries can only be set in an arbitrary way, since these eventualities can extend in time indefinitely. But there are also eventualities whose final boundaries are an intrinsic characteristic of their aspectual profile. In this case, if that final boundary is not achieved, then the predication is not appropriate for describing it.

[4] Cf. Leal \& Oliveira (2008) and Leal (2009).

[5] The term 'telicity' was first introduced by Garey (1957), but, since then, some different ways to understand it were used. See, for instance, Dowty (1991) and Krifka (1992), but also Krifka (1998) and Depraetere (1995), among many others. 
That information contemplates three possible values:

[- telic] - the verb is lexically atelic and as such it does not permit the construction in which occurs to be telic by aspectual composition in what concerns the inner aspect;

[+ telic] - the verb is lexically telic and as such it does not permit the construction in which occurs to be atelic by aspectual composition in what concerns the inner aspect;

[ $\alpha$ telic] - the verb is underspecified in what concerns the telicity of the predication, which will be determined by some other elements like, for instance, an internal argument.

There are verbs lexically marked as [- telic], which means that these verbs arise from the lexicon as atelic items and thus they do not allow the predication in which they occur to acquire telicity in the course of the aspectual composition, as seen in (9).

$$
\begin{aligned}
& \text { O rapaz vagueou (até à praia) } \quad\left({ }^{*} \text { em } 15 \mathrm{~m} . / \text { durante } 15 \mathrm{~m} .\right) \\
& \text { The boy wandered (up to the beach) } \\
& \text { The boy wandered (up to the beach) }\left({ }^{*} \text { in } 15 \mathrm{~m} . / \text { for } 15 \mathrm{~m}\right. \text {.) } \\
& \text { The } 15 \mathrm{~m} \text {.) }
\end{aligned}
$$

We can see, in (9), that the predication is compatible only with the adverbial for $x$ time and it is not compatible with in $x$ time, independently of the occurrence of a prepositional phrase with the semantic role of Goal (até à praia), which usually favours a telic reading of the predications with movement verbs (cf. Krifka 1998; Rothstein 2004; Zwarts 2005, among others). In other words, in the inner aspect (verb and its arguments), as much as in the outer aspect (with certain nonargument expressions), the predication is atelic, that is, it is an Activity, and this is related, according to our proposal, to the fact that the verb exhibits some lexical information that imposes atelicity to the predication. Thus a predication with this kind of verbs will be classified as an Activity

On the other hand, there are verbs that are lexically marked as [+ telic], ${ }^{6}$ i.e., verbs that have an information of telicity in the lexicon, which implies that these verbs do not allow that the predications in which they occur can be compositionally defined as atelic. For this reason, when these verbs occur with atelicity triggers, such as argument cumulative nouns, it is not the case that predications

[6] We are assuming a point of view similar to Engelberg (2002), who claims, grounded on German data, that a certain type of verbs, such as promovieren (to do a Ph.D) or dinieren (to dine), arise from the lexicon as quantized predicates, contrary to other authors, such as Krifka (1998), who claims that, from a strictly lexical point of view, all verbs are cumulative predicates. 
become atelic, as we can see in (10-a). The atelicity only arises, possibly as a pragmatic effect, when the whole predication is in the scope of an aspectual shifter, such as the adverbial for $x$ time in $(10-b)^{7}$.

a. O rapaz almoçou sopa em $10 \mathrm{~m}$.

The boy lunched soup in $10 \mathrm{~m}$.

The boy had soup for lunch in $10 \mathrm{~m}$.

b. O rapaz almoçou durante $10 \mathrm{~m}$.

The boy lunched for $10 \mathrm{~m}$.

The boy lunched for $10 \mathrm{~m}$. (he finished the lunch/

he didn't finish the lunch)

Almoçar (to have lunch/to lunch) is a verb that is lexically marked as [+ telic]. So, the predication this verb projects must be also telic. In other words, a predication with almoçar (to have lunch) is, in what concerns the inner aspect, an Accomplishment. Thus, in (10-a), the occurrence, as a direct object, of the cumulative noun sopa (soup) does not interfere with the telicity of the predication (that remains telic), as we can verify by the occurrence of the adverbial in $x$ time. The occurrence of an adverbial as for $x$ time, as in (10-b), does not shift the aspectual profile of the predication and, as a consequence, predications in (10) correspond to Accomplishments, irrespective of the adverbials.

Finally, there are verbs lexically specified as [ $\alpha$ telic], which means that these verbs are lexically underspecified in what concerns telicity. It is in these cases that the internal arguments of the verbs partially determine the aspectual profile of the predications. See (11).

a. O rapaz bebeu leite (durante 10 segundos/* em 10 segundos) The boy drunk milk (for 10 seconds/in 10 seconds)

The boy drank milk (for 10 seconds/in 10 seconds)

[7] A referee considered examples (10) ungrammatical. However, the Web has several examples with this kind of combination. See, for instance, the following ones.

(a) a Dona Constança também acredita que uns dias antes o Sócrates almoçou durante $3 \mathrm{~h}$ com Pinto Monteiro para falar de livros

(http://www.tvi24.iol.pt/opiniao/constanca-cunha-e-sa/

entrevista-a-tvi-prenuncia-nova-estrategia-de-defesa-de-socrates)

(b) 0 réu jantou, durante 45 minutos, compreendidos entre as 19 horas e 30 minutos e as 20 horas e 45 minutos do dia 30/03/2003, sendo que durante o jantar bebeu, pelo menos, 0,75 litros de vinho

(http://www.dgsi.pt/jtrc.nsf/8fe0e606d8f56b22802576c0005637dc/

a6f159ccc5a9c43d802572ec003aa944?0penDocument) 
b. O rapaz bebeu um copo de leite (*/\# durante dez segundos/ em dez segundos)

The boy drunk a glass of milk (for 10 seconds/ in 10 seconds)

The boy drank a glass of milk (for 10 seconds/in $10 \mathrm{~s}$ seconds)

We can see in (11) that the occurrence of a non count bare noun in the direct object position determines the atelicity of the predication, while the occurrence of a measure function as um copo de (a glass of) determines the telicity of the predication, as it is confirmed by the different possibilities of combination with the adverbial in $x$ time and for $x$ time.

The same happens with verbs of movement plus a Goal prepositional phrase, as in (12).

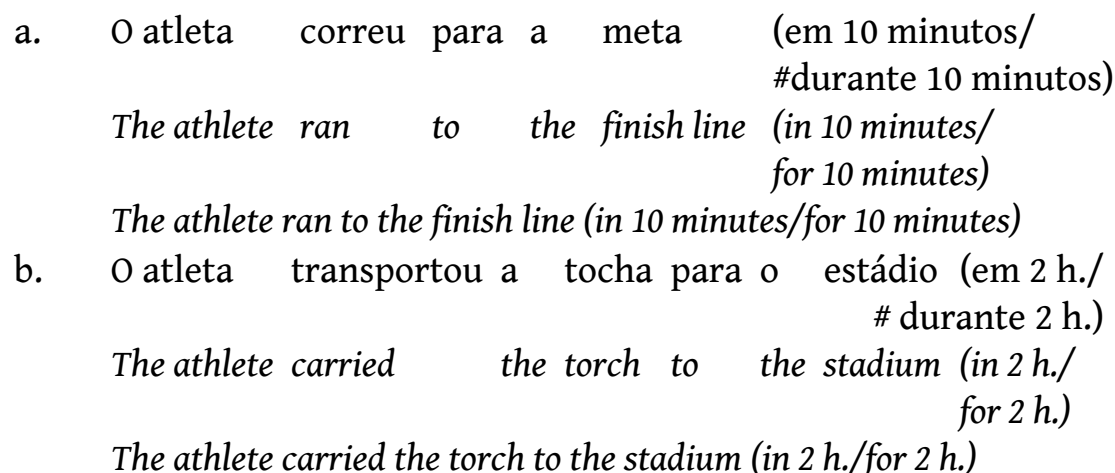

However, the class of [ $\alpha$ telic] verbs does not seem to be uniform. Instead, it seems that there is a scale of (a)telicity. For instance, verbs like beber (to drink) or correr (to run) seem to be more "telic" than verbs like discutir (to discuss) ou estudar (to study), since the latter, but not the former, allow not only telic readings, but also atelic ones when the direct object is a quantized predicate. In fact, when the internal argument of these verbs is realized as a quantized predicate, a reading of Activity and a reading of Accomplishment of the verbal predicate are both possible ${ }^{8}$, which is in contrast with the majority of the previous cases, where a reading of Accomplishment is usually mandatory. In these circumstances, these

[8] The difference between this two readings seem to rely on some notion of "completeness", that is related to telicity. For instance, Rothstein (2008) argues that the telic/atelic distinction bear on the denotation of the verbal predicates: telic predicates denote sets of atomic entities, whereas atelic predicates denote sets of non-atomic entities. The difference between these sets depends on the existence of criteria for what counts as 'one entity'. If we say that the deputies discussed the law in 2 hours, this means that the discussion come to an end, i.e., the discussion had a predetermined procedure that was completed and this procedure defines what counts as one event of 'discussing the law'. This interpretation does not arise with the "for $\mathrm{x}$ time" adverbial. This is very different from what Dahl (1981) suggests for the relation between the $\mathrm{P}$ property and the $\mathrm{T}$ property , that is the relation between telic/atelic and bounded/unbounded. For a discussion of this latter proposal, see also Depraetere (1995). 
constructions with verbs such as estudar or discutir can equally combine with in $x$ time and for $x$ time, as (13) shows.

$$
\begin{aligned}
& \text { Os deputados discutiram a lei (durante } 2 \text { horas/em } 2 \text { horas) } \\
& \text { The deputies discussed the law (for } 2 \text { hours/in } 2 \text { hours) } \\
& \text { The deputies discussed the law (for } 2 \text { hours/in } 2 \text { hours) }
\end{aligned}
$$

It is important to notice that, even in the cases in which a measure adverbial occurs, the described situation is relatively homogeneous, being, in this respect, similar to Activities. This notion of 'homogeneity' can be described in a way very similar to the notion of 'incremental homogeneity', proposed in Landman (2008), and further developed in Landman \& Rothstein $(2012)^{9}$. In fact, if it is true that os deputados discutiram a lei em 2 horas (the deputies discussed the law in 2 hours), it is also true that os deputados discutiram a lei in subintervals of those two hours. On the contrary, if it is true that o rapaz bebeu um copo de leite em 10 segundos (the boy drunk a glass of milk in 10 seconds), then o rapaz bebeu um copo de leite cannot be true in any subinterval of those 10 seconds, which means that Accomplishments are not homogeneous.

All in all, [- telic] verbs project eventualities that can be classified, concerning the inner aspect, as Activities, while [+ telic] verbs project Accomplishments, independently of the properties of their arguments. On the other hand, [ $\alpha$ telic] verbs project eventualities whose telicity will depend, for instance, on the properties of an argument (if any), the one that establishes a homomorphism with the run time of the eventuality. If we consider, just like Filip (1999), non saturated predicates, i.e., predicates whose argument positions are not filled yet, these predicates will be Activities, if the verb is [- telic], or Accomplishments, if the verb is [+ telic], or some sort of "Accomplishable Activities" (meaning Activities that can become Accomplishments) if the verb is [ $\alpha$ telic]. In fact, and as it is usually recognized in the literature, in the absence of the internal argument realization (in the cases where this is possible), the predication is an Activity, as we can see in (14). When the argument slots are occupied, predications will be defined, in principle, as Activities or as Accomplishments, depending on the denotational properties of the homomorphic argument ${ }^{10}$, or, instead, as in Kennedy \& Levin (2008), on the existence of a measure of change function whose scale can have or have not a terminal point.

$$
\begin{aligned}
& \text { O rapaz bebeu (durante } 10 \text { segundos/* em } 10 \text { segundos }{ }^{11} \text { ) } \\
& \text { The boy drunk (for } 10 \text { seconds / in } 10 \text { seconds) } \\
& \text { The boy drunk (for } 10 \text { seconds / in } 10 \text { seconds) }
\end{aligned}
$$

[9] The complex notion of 'homogeneity' was first noticed in Vendler (1957).

[10] Verbs like "estudar" and "discutir" are exceptions to this statement, as we have seen before.

[11] Except if a delimited portion of beverage is considered. 
To sum up, we propose that [+ telic], [- telic] and [ $\alpha$ telic] are lexical verbal features. Furthermore, these features are different concerning the aspectual composition: [+ telic] and [- telic] features determine the telicity of the basic predication, irrespective of the nature of the arguments; but the $[\alpha$ telic] feature allows the telicity of the predication to be determined during the derivation process. In this case, the quantized/cumulative properties of the homomorphic argument are aspectually relevant. According to this proposal, based on EP data, the telicity of the predication is not determined at V level in all cases (cf., for instance, Tenny 1994), nor solely at VP level (cf., for instance, Rothstein 2012). It is possible that languages diverge in the way they compute telicity (cf., for instance, Filip \& Rothstein 2006, for Slavic languages).

\section{[4] FINAL REMARKS}

The problem we concentrated on was to clarify the aspectual status of some predications regarding in particular the problem of telicity. These predications can have a different classification according to the quantized/cumulative nature of one of their arguments. That is, they can be classified as Accomplishments or Activities in their inner aspect. This is a long debate as we pointed out mentioning some of the most relevant bibliography. The two proposals that we briefly discussed (Filip 1999; Piñon 2006) do not seem to solve some of the problems put forward for the EP data presented.

We then proposed that the verbs carry some aspectual information concerning the telicity of the predication they project. So, based on EP data, we suggest that there are three possible values: [+ telic], [- telic] verbs and [ $\alpha$ telic] verbs. The former determine the telicity or atelicity of the predication irrespective of the nature of the arguments. The latter one does not do so. In this case, the telicity of the predication will rely on other elements. We only discussed cases where an argument establishes a homomorphic relation to the event. When this relation holds, the argument determines if the predication is telic or atelic, depending on its denotational properties.

We also propose that, when the verbs are [ $\alpha$ telic] and none of the relevant arguments is fulfilled, the predication will be atelic and consequently it is classified as an Activity. So, when the predications projected by the $[\alpha$ telic] verbs are not saturated, in fact they are not Accomplishments nor Activities, but Accomplishable Activities, i.e., Activities that can have culmination.

\section{ACKNOWLEDGMENTS}

This paper is dedicated to Belinda Maia, whose activities and accomplishments are of great importance.

CLUP is supported by FCT, PEst-OE/LIN/UI0022/2014. 


\section{REFERENCES}

Bach, Emmon. 1986. The Algebra of Events. Linguistics and Philosophy 9. 5-16.

Carlson, Lauri. 1981. Aspect and Quantification. In Philip Tedeschi \& Annie Zaenen (eds.), Syntax and Semantics, vol. 14, chap. 3, 31-64. Academic Press.

Dahl, Osten. 1981. On the Definition of the Telic-Atelic (Bounded-Nonbounded) Distinction. In Philip Tedeschi \& Annie Zaenen (eds.), Syntax and Semantics, vol. 14, chap. 5, 79-90. Academic Press.

Declerck, Renaat. 1979. Aspect and the bounded/unbounded (telic/atelic) distinction. Linguistics 17. 761-794.

Depraetere, Ilse. 1995. On the necessity of distinguishing between (un)boundedness and (a)telicity. Linguistics and Philosophy 18(1). 1-19.

Dowty, David (ed.). 1979. Word Meaning and Montague Grammar. The Semantics of Verbs and Times in Generative Semantics and in Montague's PTQ. Reidel.

Dowty, David. 1991. Thematic Proto-Rules and Argument Selection. Language 67(3). 547-619.

Engelberg, Stefan. 2002. Intransitive accomplishments and the lexicon: the role of implicit arguments, definiteness and reflexivity in aspectual composition. Journal of Semantics 19. 369-416.

Filip, Hana (ed.). 1999. Aspect, Eventuality Types and Nominal Reference. Garland Publishing Inc.

Filip, Hana \& Susan Rothstein. 2006. Telicity as a semantic parameter. In James Lavine, Steven Franks, Mila Tasseva-Kurktchieva \& Hana Filip (eds.), Formal Approaches to Slavic Linguistics, vol. 14, 139-156. Ann Arbor.

Garey, Howard. 1957. Verbal Aspect in French. Language 33(2). 91-110.

Hay, Jen, Christopher Kennedy \& Beth Levin. 1999. Scalar structure underlies telicity in "degree achievements" . In Tanya Matthews \& Devon Strolovitch (eds.), Proceedings of SALT 9, 127-144.

Kennedy, Christopher \& Beth Levin. 2008. Measure of Change: The Adjectival Core of Degree Achievements. In Louise McNally \& Christopher Kennedy (eds.), Adjectives and Adverbs: Syntax, Semantics and Discourse, chap. 7, 156-182. Oxford University Press.

Kenny, Anthony (ed.). 1963. Action, Emotion and Will. Humanities Press. 
Krifka, Manfred. 1992. Thematic Relations as Links between Nominal Reference and Temporal Constitution. In Ivan Sag \& Anna Szabolcsi (eds.), Lexical Matters, chap. 2, 29-54. Stanford University.

Krifka, Manfred. 1995. Common Nouns: A Contrastive Analysis of Chinese and English. In Gregory Carlson \& Francis Pelletier (eds.), The Generic Book, chap. 11, 398-411. The University of Chicago Press.

Krifka, Manfred. 1998. The Origins of Telicity. In Susan Rothstein (ed.), Events and Grammar, chap. 9, 197-235. Kluwer Academic Publishers.

Landman, Fred. 2008. On the differences between the tense-perspective-aspect systems of English and Dutch. In Susan Rothstein (ed.), Theoretical and Crosslinguistic Approaches to the Semantics of Aspect, chap. 4, 107-166. Benjamins.

Landman, Fred \& Susan Rothstein. 2012. The felicity of aspectual for-phrases, part 2: incremental homogeneity. Language and Linguistic Compass 6(2). 97-112.

Leal, António. 2009. Semântica Aspectual e Nominal - Contributo das Expressões Nominais para a Construção Aspectual das Frases: Faculdade de Letras da Universidade do Porto PhD dissertation.

Leal, António \& Fátima Oliveira. 2008. Subtipos de verbos de movimento e classes aspectuais. In Sónia Frota \& Ana Lúcia Santos (eds.), Textos Seleccionados do XXIII Encontro da Associação Portuguesa de Linguística, 287-298. Associação Portuguesa de Linguística.

Moens, Marc. 1987. Tense, Aspect and Temporal Reference: University of Edinburgh PhD dissertation.

Mourelatos, Alexander. 1978. Events, Processes and States. Linguistics and Philosophy 2. 415-434.

Piñon, Christopher. 2006. Weak and strong accomplishments. In Katalin Kiss (ed.), Event structure and the left periphery: Studies on Hungarian, chap. 5, 91-106. Springer.

Ramchand, Gillian (ed.). 1997. Aspect and Predication - The Semantics of Argument Structure. Clarendon Press.

Rothstein, Susan (ed.). 2004. Structuring Events: a Study in the Semantics of Lexical Aspect. Blackwell.

Rothstein, Susan. 2008. Two puzzles for a theory of lexical aspect: semelfactives and degree achievements. In Johannes Dölling, Tatjana Heyde-Zybatow \& Martin Schäfer (eds.), Event Structures in Linguistic Form and Interpretation, chap. 8, 175-198. Walter de Gruyter. 
Rothstein, Susan. 2012. Another Look at Accomplishments and Incrementality. In Violeta Demonte \& Louise McNally (eds.), Telicity, Change and State. A CrossCategorial View of Event Structure, chap. 3, 60-102. Oxford University Press.

Santos, Diana Maria de Sousa Marques Pinto dos. 1996. Tense and aspect in English and Portuguese: a contrastive semantical study: Instituto Superior Técnico, Universidade Técnica de Lisboa PhD dissertation.

Smith, Carlota (ed.). 1991. The Parameter of Aspect. Kluwer Academic Publishers.

de Swart, Henriette. 1998. Aspect shift and coercion. Natural Language and Linguistic Theory 16(2). 347-385.

Tenny, Carol. 1987. Grammaticalizing Aspect and Affectedness: Massachusetts Institute of Technology PhD dissertation.

Tenny, Carol (ed.). 1994. Aspectual Roles and the Syntax-Semantics Interface. Kluwer.

Vendler, Zeno. 1957. Verbs and Times. The Philosophical Review 66(2). 143-160.

Verkuyl, Henk (ed.). 1972. On the Compositional Nature of the Aspects. Reidel Publishing.

Verkuyl, Henk (ed.). 1993. A Theory of Aspectuality. The interaction between temporal and atemporal structure. Cambridge University Press.

Zwarts, Joost. 2005. Prepositional Aspect and the Algebra of Paths. Linguistics and Philosophy 28(6). 739-779.

CONTACTS

Fátima Oliveira

Faculdade de Letras da Universidade do Porto

moliv@letras.up.pt

António Leal

Faculdade de Letras da Universidade do Porto

jleal@letras.up.pt 